\title{
BUDAYA SEKOLAH UNTUK MENINGKATKAN \\ PRESTASI AKADEMIK
}

(Studi pada Madrasah Tsanawiyah Muhammad Basiuni Imran Sambas)

\section{Oleh \\ Fitriani $^{1}$}

\begin{abstract}
Abstrak: Pentingnya membangun budaya organisasi di sekolah terutama berkenaan dengan upaya pencapaian tujuan pendidikan sekolah dan peningkatan kinerja sekolah. Proses pendidikan tidak akan terjadi dengan sendirinya melainkan harus direncanakan, diprogram, dan difasilitasi dengan dukungan dan partisipasi aktif guru sebagai pendidik.

Penelitian ini menggunakan pendekatan kualitatif. Teknik pengumpulan data yang digunakan meliputi(1) pengamatan/observasi (2) wawancara mendalam (3) studi dokumentasi. Semua data yang diperoleh dari ketiga teknik tersebut diorganisasikan, ditafsirkan, dan dianalisis guna menyusun temuan di lapangan. Temuan dalam penelitian ini adalah (1) nilai-nilai yang berlaku untuk membangun budaya sekolah di Madrasah Tsanawiyah Muhammad Basiuni Imran Sambas ; (2)budaya organisasi yang dilakukan warga sekolah; (3) prestasi yang dicapai Madrasah Tsanawiyah Muhammad Basiuni Imran Sambas, serta (4) faktor- faktor yang menjadi pendukung dan penghambat penerapan nilai-nilai budaya sekolah di Madrasah Tsanawiyah Muhammad Basiuni Imran Sambas.
\end{abstract}

Kata kunci : Budaya Sekolah, Prestasi Akademik.

\section{Pendahuluan}

Pemahaman tentang budaya sekolah amat penting bagi upaya pengembangan organisasi sekolah. Karena, keberhasilan sebuah lembaga pendidikan tidak hanya didukung oleh lengkapnya sarana dan prasarana, guru yang berkualitas ataupun input siswa yang baik, tetapi budaya sekolah sangat berperan terhadap peningkatan keefektifan sekolah.

Asumsi tersebut diperkuat oleh Mayer dan Rowen dalam Ade Suherman (2008:24) yang menyatakan "budaya sekolah merupakan jiwa (spirit) sebuah sekolah yang memberikan makna terhadap kegiatan kependidikan sekolah tersebut, jika budaya sekolah lemah, maka ia tidak

\footnotetext{
${ }^{1}$ Fitriani adalah guru Madrasah Tsanawiyah Muhammad Basiuni Imran Sambas
} 
kondusif bagi pembentukan sekolah efektif. Sebaliknya budaya sekolah yang kuat akan menjadi fasilitator bagi peningkatan sekolah efektif'.

Sebagaimana studi yang dilakukan Leslie J. Fyans, Jr. dan Martin L. Maehr (dalam Syafaruddin, 2010:172) tentang pengaruh dari lima dimensi budaya organisasi di sekolah yaitu: (1) tantangan akademik, (2) prestasi komparatif, (3) penghargaan terhadap prestasi, (4) komunitas sekolah, dan (5) persepsi tentang tujuan sekolah menunjukkan survey terhadap 16.310 murid pada kelas empat, enam, delapan dan sepuluh pelajar dari 820 sekolah negeri di Illinois, mereka lebih termotivasi untuk belajar dalam sekolah yang kulturnya kuat".

Selanjutnya Peterson (dalam Karmidah, 2007:8) Ada beberapa peran kepala sekolah pembentuk budaya yang positif:

Pertama, melanjutkan untuk mendukung budaya yang positif dengan cara menyampaikan inti misi sekolah, bersemangat dan merayakan kejadian/ kegiatan positif yang berlangsung. Kedua, menilai budaya, berusaha memahami budaya itu ingin melihat apa saja yang positif, suportif dan saling mendukung dalam budaya itu yang perlu diperkuat. Ketiga, mencari cara bagaimana merayakan dan mendukung hal-hal positif yang terjadi. Keempat, melihat dari dekat tradisi di sekolah, dalam memperkuat nilai inti dan misi sekolah.

Budaya sekolah merupakan ciri khas, karakter atau watak, dan citra sekolah tersebut di masyarakat luas. Madrasah Tsanawiyah Muhammad Basiuni Imran Sambas mempunyai misi sebagai berikut.

1. Selalu berorientasi dalam proses pembinaan nilai-nilai Agama dalam kehidupan sehari-hari.

2. Menyelenggarakan proses belajar mengajar dan bimbingan secara optimal, efektif, dan efesien.

3. Menyelenggarakan kegiatan pembinaan ekstrakurikuler sekolah.

4. Selalu berorientasi dalam menumbuhkan semangat keunggulan dan prestasi pada seluruh insan yang ada di Sekolah.

Madrasah Tsanawiyah Muhammad Basiuni Imran Sambas telah memiliki sistem pengembangan budaya sekolah yang terintegrasi dan terimplementasi dalam proses pembelajaran. Semuanya itu telah menyatu ke dalam kegiatan akademik dan kegiatan kesiswaan melalui kegiatan yang bersifat intrakurikuler dan ekstrakurikuler. 
Sebagai suatu organisasi, sekolah mempunyai budaya yang berbedabeda. Menurut Uhar Suharsaputra (2010:107) mengemukakan "kultur sekolah merupakan kepribadian organisasi yang membedakan antara satu sekolah dengan sekolah lainnya, bagaimana seluruh anggota organisasi sekolah berperan dalam melaksanakan tugasnya tergantung pada keyakinan, nilai dan norma yang menjadi bagian dari kultur sekolah tersebut".

Edgar H. Schein (2004 :17) mendefinisikan bahwa budaya adalah: A pattern of share basic assumption that the group learner as it solved its problems of external adaptation and internal integration, that has worked well enough to be considered valid and therefore, to be taught to new members as the correct way to perceive, think and feeling relation to these problems.

Pendapat di atas diartikan bahwa budaya adalah "suatu pola asumsi dasar yang diciptakan, ditemukan atau dikembangkan oleh kelompok tertentu sebagai pembelajaran untuk mengatasi masalah adaptasi eksternal dan integrasi internal yang resmi dan terlaksana dengan baik dan oleh karena itu, diajarkan kepada anggota-anggota baru sebagai cara yang tepat untuk memahami, memikirkan dan merasakan terkait dengan masalah-masalah tersebut.

Budaya yang ada di sekolah dibagi dua, yaitu budaya yang mempunyai nilai-nilai primer, yaitu (1) tujuan organisasi sekolah;(2) konsensus dan komitmen terhadap tugas; (3) keunggulan; (4) kesatuan kepentingan (5) imbalan berdasarkan prestasi; (6) empiris; (7) keakraban dan (8) integritas. Sedangkan budaya yang bernilai sekunder, yaitu (1) penerima layanan; (2) pengendalian yang disiplin; (3) kemandirian; (4) pengambilan keputusan yang cepat; (5) visioner; dan (6) pengembangan (Miller dalam Ridwan, 2009: 113).

Selanjutnya Kasali (dalam Muhaimin, Suti'ah, 2010: 54) mengemukakan nilai-nilai yang menjadi pilar budaya sekolah/madrasah dapat diprioritaskan pada nilai-nilai tertentu. Nilai-nilai yang diprioritaskan meliputi inovatif, adaptif, bekerja keras, peduli terhadap orang lain, disiplin, jujur, berwawasan luas, inisiatif, kebersamaan, tanggungjawab, rasa memiliki, komitmen terhadap lembaga, saling pengertian, semangat persatuan, memotivasi dan membimbing.

Kenyataan sehari-hari seringkali terjadi pelanggaran terhadap peraturan sekolah, masih banyak siswa yang bertingkah laku kurang baik dan kurang benar serta tidak dapat mengendalikan dorongan dirinya yang selalu berubah- 
ubah. Pelanggaran terhadap kedisiplinan di sekolah yang sering terjadi meliputi jenis pelanggaran terlambat masuk sekolah, bolos saat jam pelajaran, dan berpakaian tidak sesuai dengan ketentuan.

Peneliti tertarik untuk meneliti budaya sekolah pada Madrasah Tsanawiyah Muhammad Basiuni Imran Sambas, alasannya: Pertama, Apa yang dapat dipelajari dari Madrasah Tsanawiyah Muhammad Basiuni Imran Sambas. Guna menjelaskan bagaimana sebuah SMP menjadi baik atau berprestasi, dapat dilihat dari budaya organisasi sekolah tersebut. Aspek ini merupakan elemen yang sangat berpengaruh dalam membentuk sikap dan perilaku seseorang. Kedua, Madrasah Tsanawiyah Muhammad Basiuni Imran Sambas memiliki prestasi non akademik yang membanggakan. Namun bagaimana dengan pencapaian prestasi akademiknya? Ketiga, dengan penerapan budaya sekolah yang positif, diharapkan madrasah mampu menghasilkan peserta didik yang berprestasi baik di bidang akademik maupun non akademik.

Berdasarkan uraian tersebut dan memperhatikan budaya sekolah yang diterapkan oleh pihak sekolah dapat mempengaruhi kepribadian siswa terutama dalam hal prestasi akademik. Oleh karena itu, penelitian ini difokuskan pada kajian budaya sekolah yang diterapkan Madrasah Tsanawiyah Muhammad Basiuni Imran Sambas, sehingga input peserta didik yang biasa dapat membawa peserta didik menjadi output yang berprestasi tinggi.

\section{Masalah}

1. Nilai-nilai apa saja yang berlaku untuk membangun budaya sekolah dalam mencapai prestasi akademik di Madrasah Tsanawiyah Muhammad Basiuni Imran Sambas?

2. Bagaimana sekolah menerapkan nilai-nilai budaya di Madrasah Tsanawiyah Muhammad Basiuni Imran Sambas?

3. Bagaimana prestasi akademik di Madrasah Tsanawiyah Muhammad Basiuni Imran Sambas?

4. Faktor- faktor apa yang menjadi pendukung dan penghambat penerapan nilai-nilai budaya sekolah di Madrasah Tsanawiyah Muhammad Basiuni Imran Sambas? 


\section{Tujuan Penelitian}

Sesuai dengan permasalahan yang dikemukakan di atas, maka penelitian ini bertujuan untuk : (1) Mendeskripsikan nilai-nilai yang berlaku untuk membangun budaya sekolah dalam mencapai prestasi akademik di Madrasah Tsanawiyah Muhammad Basiuni Imran Sambas (2) Mendeskripsikan bagaimana sekolah menerapkan nilai-nilai budaya di Madrasah Tsanawiyah Muhammad Basiuni Imran Sambas (3) Mendeskripsikan prestasi akademik di Madrasah Tsanawiyah Muhammad Basiuni Imran Sambas Mendeskripsikan faktor-faktor yang menjadi pendukung dan penghambat penerapan nilai-nilai budaya sekolah di Madrasah Tsanawiyah Muhammad Basiuni Imran Sambas

\section{Manfaat Penelitian}

Hasil penelitian ini diharapkan dapat dijadikan sebagai salah satu bagian kajian dalam upaya mendalami ilmu budaya sekolah sebagai salah satu strategi peningkatan mutu sekolah. Selanjutnya, temuan penelitian ini diharapkan dapat memberi sumbangan terhadap upaya memahami pentingnya pembinaan budaya sekolah sebagai salah satu strategi untuk meningkatkan mutu sekolah serta memberikan kontribusi akademis dalam upaya peningkatan dan pengembangan ilmu pengetahuan khususnya di bidang kepemimpinan lembaga pendidikan.

\section{Metode Penelitian}

Penelitian ini menggunakan pendekatan kualitatif. Peneliti bertindak sebagai instrumen sekaligus mengumpul data sehingga dapat dikatakan sebagai instrumen kunci. Peneliti dalam hal ini melakukan observasi, wawancara dan mengambil dokumen.

Bentuk wawancara yang digunakan peneliti adalah wawancara mendalam dan semua pertanyaan sesuai dengan apa yang dilihat, didengar, dirasakan pada saat pewawancara bersama responden. Lokasi penelitian adalah Madrasah Tsanawiyah Muhammad Basiuni Imran Sambas. Sumber data dalam penelitian ini yaitu Kepala Sekolah, Wakil Kepala Sekolah bagian Kurikulum, Kesiswaan, Wali Kelas, Guru, Siswa, Penjaga Warung dan penyedia Katering.

Menurut Miles dan Hubermen (1992:20) "ada tiga macam kegiatan dalam analisis data kualitatif, yaitu reduksi data, model data (data display) 
dan penarikan/Verifikasi Kesimpulan". Reduksi data dan penyajian hasilnya dilakukan terus menerus selama pengumpulan data berlangsung. Data yang berupa benda, gambar-gambar, rekaman, serta informasi diubah menjadi data verbal, berupa kata-kata yang tersusun menjadi kalimat-kalimat dan paragraf. Dari hasil tersebut, ditarik kesimpulan. Semua data yang diperoleh dari ketiga teknik tersebut diorganisasikan, ditafsirkan, dan dianalisis guna menyusun temuan di lapangan. Sedangkan keabsahan data diuji dengan: (1) kepercayaan (2) keteralihan (3) kebergantungan (4) kepastian. Uji Kredibilitas data atau kepercayaan terhadap data hasil penelitian kualitatif antara lain dilakukan dengan perpanjangan pengamatan, peningkatan ketekunan dalam penelitian, triangulasi, diskusi dengan teman sejawat, analisis kasus negatif, dan member check.

\section{Pembahasan Hasil Penelitian}

1. Nilai-nilai yang ditemukan untuk membangun budaya sekolah dalam mencapai prestasi akademik di Madrasah Tsanawiyah Muhammad Basiuni Imran Sambas yaitu keikhlasan, kejujuran, disiplin, kerjasama, kerja keras, demokratis, toleransi, dan cinta tanah air.

Nilai-nilai tersebut telah memberikan warna tersendiri pada Madrasah Tsanawiyah Muhammad Basiuni Imran Sambas. Membentuk karakteristik siswa Madrasah Tsanawiyah Muhammad Basiuni Imran Sambas yang membedakannya dengan sekolah-sekolah lainnya di Kabupaten Sambas.

Selain apa yang dipaparkan diatas hal penting lain yang dapat dicermati dari penelitian di Madrasah Tsanawiyah Muhammad Basiuni Imran Sambas adalah keberhasilan sosialisasi nilai-nilai religius yang dipelopori oleh kepala sekolah seperti saling menyapa, serta menghormati di antara aktor-aktor di Madrasah Tsanawiyah Muhammad Basiuni Imran Sambas dan sopan santun telah menjelma dalam kehidupan sehari- hari di sekolah.

2. Penerapan nilai-nilai budaya dilaksanakan melalui kegiatan sebagai berikut.

a. Nilai keikhlasan dilakukan melalui pembiasaan dan keteladanan yang dimulai dari pimpinan madrasah, guru/pengasuh dan pengurus pondok. 
b. Nilai Jujur, penerapannya siswa-siswi Madrasah Muhammad Basiuni Imran dilarang keras untuk mencontek saat ulangan dan mendirikan "Warung Kejujuran".

c. Nilai Disiplin, misalnya siswa yang datang terlambat ke sekolah, tidak mengerjakan pekerjaan rumah/tugas yang diberikan oleh guru akan diberikan sanksi.

d. Nilai kerjasama, penerapannya seperti dalam suatu kerja kelompok untuk menyelesaikan suatu tugas atau masalah, serta dalam bakti sosial pada Jumat dan Minggu bersih, class meeting, school meeting, mukhadaroh, senam santri, kegiatan ekstrakurikuler dan pengajian

e. Nilai kerja keras, penerapannya dalam kegiatan belajar mengajar di dalam maupun di luar kelas. Menggunakan waktu secara efektif untuk menyelesaikan tugas-tugas, sikap dan perilaku yang tidak mudah tergantung pada orang lain dalam menyelesaikan tugas-tugas.

f. Nilai Demokratis, penerapannya pemilihan keanggotaan OSIS yang melibatkan semua siswa, rapat- rapat yang diadakan di sekolah.

g. Nilai toleransi diimplementasikan dengan menghargai perbedaanperbedaan yang ada diantara santri baik keluarga, status sosial maupun karakter masing-masing.

h. Nilai Cinta Tanah Air penerapannya, melalaui upacara Bendera setiap senin.

3. Prestasi akademik Madrasah Tsanawiyah Muhammad Basiuni Imran Sambas.

Berdasarkan nilai hasil Ujian Nasional tahun 2009/2010 untuk Negeri dan Swasta tingkat SMP/MTs, Madrasah Tsanawiyah Muhammad Basiuni Imran mendapat peringkat ke-2 dan untuk Swasta peringkat pertama. Sedangkan Berdasarkan hasil Ujian Nasional SMP/MTs tahun ajaran 2010/2011, Madrasah Tsanawiyah Muhammad Basiuni Imran Sambas ranking 41 dari 118 sekolah tingkat kabupaten.

Prestasi Akademik Siswa bervariasi, ada yang tinggi/baik, sedang dan ada yang kurang. Sering juga mendapat juara pada lomba Olimpiade. Walaupun siswa pada umumnya yang masuk adalah siswa yang kurang, tetapi dengan kemauan yang tinggi dan polesan dari guru. Siswa tersebut bisa juga berprestasi. Serta dipengaruhi oleh lingkungan 
orang-orang /dapat kawan yang baik sehingga mendapat pengaruh yang baik juga.

Kondisi di atas menunjukkan bahwa pengaruh nilai-nilai budaya sekolah yang dilaksanakan di Madrasah Tsanawiyah Muhammad Basiuni Imran Sambas memberikan dampak positif bagi peningkatan prestasi akademik siswa/santri. Sementara Prestasi Non Akademik yang pernah diraih oleh Madrasah Tsanawiyah Muhammad Basiuni Imran Sambas antara lain: 26 - 28 Desember 2010 Pidato Bahasa Indonesia Putri TQA (Juara 1), Pidato Bahasa Indonesia Putra TQA (Juara 2), Pidato Bahasa Inggris Putra TQA ( Juara 3), Pidato Bahasa Arab Putri TQA (Juara 2), Pidato Bahasa Arab PutraTQA (Juara 1), Tarjamah Lafdziyah (Juara 1), Khattil Qur'an Putri TQA (Juara 3), Khattil Qur'an Putra TQA (Juara 1), Debat Bahasa Arab Tk Propinsi (Juara 1), Pidato Bahasa Indonesia Putri TQA (26-28 Juni 2011) Juara 1, dan Tarjamah Lafdziyah TQA (26-28 Juni 2011) Juara 2.

Apa yang dicapai oleh sekolah, kiranya merepresentasikan hasil kerja keras dan kerjasama dari warga sekolah dalam upaya meningkatkan prestasi siswa. Nilai-nilai budaya tersebut dapat mereka jadikan kekuatan dalam lingkungan belajar, dalam setiap aktivitas untuk pencapaian prestasi .

4. Faktor-faktor pendukung dan penghambat penerapan nilai-nilai budaya di Madrasah Tsanawiyah Muhammad Basiuni Imran.

Faktor-faktor pendukung antara lain: Tenaga pengasuh dan pengajar yang memadai, Santri/siswa sebagian besar berada dalam lingkungan pondok/asrama, sehingga mudah untuk memonitor dan menggerakkan mereka,

kerjasama dan dukungan yang kuat dari siswa/santri dan orangtua, lingkungan pondok/madrasah yang luas, nyaman dan kondusif serta rasa kekeluargaan yang kental antara siswa/santri, guru/pengasuh maupun pengurus pondok.

Adapun faktor penghambat antara lain: kesiapan para siswa/santri terutama untuk menyesuaikan diri dengan suasana madrasah/pondok, kesulitan untuk memonitor para siswa/santri yang berada di luar lingkungan pondok, sehingga faktor lingkungan sosial dari luar juga perpengaruh terhadap penerapan nilai-nilai budaya di Madrasah, ada 
keluhan orangtua tentang jadual kegiatan di madrasah yang terlalu padat, masih ada guru yang datang terlambat, fasilitas dan prasarana yang belum memadai.

Bagi Madrasah Tsanawiyah Muhammad Basiuni Imran Sambas, faktor-faktor penghambat ini bukan sesuatu yang membuat mereka mundur untuk mengelola institusi pendidikan yang mereka lakoni. Dari faktor-faktor penghambat ini mereka merasa terpacu untuk bersaing dengan sekolah-sekolah lain dalam mengejar prestasi. Dan terbukti hasilnya mereka dapat unggul dari beberapa sekolah umum yang memiliki beberapa kelebihan dari mereka.

\section{Kesimpulan}

Nilai-nilai yang ditemukan untuk membangun budaya sekolah dalam mencapai prestasi akademik di Madrasah Tsanawiyah Muhammad Basiuni Imran Sambas yaitu keikhlasan, kejujuran, disiplin, kerjasama, kerja keras, demokratis, toleransi, dan cinta tanah air. Adapun penerapan nilai-nilai budaya di Madrasah Tsanawiyah Muhammad Basiuni Imran Sambas antara lain sebagai berikut.

1. Nilai keikhlasan dilakukan melalui pembiasaan dan keteladanan yang dimulai dari pimpinan madrasah, guru/pengasuh dan pengurus pondok.

2. Nilai jujur, penerapannya siswa-siswi Madrasah Muhammad Basiuni Imran dilarang keras untuk mencontek saat ulangan dan mendirikan "Warung Kejujuran".

3. Nilai disiplin, misalnya siswa yang datang terlambat ke sekolah, tidak mengejakan pekerjaan rumah/tugas yang diberikan oleh guru akan diberikan sanksi.

4. Nilai kerjasama, penerapannya seperti dalam suatu kerja kelompok untuk menyelesaikan suatu tugas atau masalah, serta dalam bakti sosial pada Jumat dan Minggu bersih, class meeting, school meeting, mukhadaroh, senam santri, kegiatan ekstrakurikuler dan pengajian

5. Nilai kerja keras, penerapannya dalam kegiatan belajar mengajar di dalam maupun di luar kelas. Menggunakan waktu secara efektif untuk menyelesaikan tugas-tugas, sikap dan perilaku yang tidak mudah tergantung pada orang lain dalam menyelesaikan tugas-tugas.

6. Nilai demokratis, penerapannya pemilihan keanggotaan OSIS yang melibatkan semua siswa, rapat- rapat yang diadakan di sekolah. 
7. Nilai toleransi diimplementasikan dengan menghargai perbe daanperbedaan yang ada diantara santri baik keluarga, status sosial maupun karakter masing-masing.

8. Nilai cinta tanah air penerapannya, melalaui upacara bendera setiap senin.

Sedangkan prestasi akademik Madrasah Tsanawiyah Muhammad Basiuni Imran Sambas berdasarkan hasil Ujian Nasional tahun 2009/2010 untuk Negeri dan Swasta tingkat SMP/MTs mendapat peringkat ke-2 dan untuk Swasta peringkat pertama. Sedangkan Berdasarkan hasil Ujian Nasional SMP/MTs tahun ajaran 2010/2011, Madrasah Tsanawiyah Muhammad Basiuni Imran Sambas ranking 41 dari 118 sekolah tingkat kabupaten.

Prestasi akademik siswa bervariasi, ada yang tinggi/baik, sedang dan ada yang kurang. Sering juga mendapat juara pada lomba olimpiade. Walaupun siswa pada umumnya yang masuk adalah siswa yang kurang, tetapi dengan kemauan yang tinggi dan polesan dari guru. Siswa tersebut bisa juga berprestasi. Serta dipengaruhi oleh lingkungan orang-orang/dapat kawan yang baik sehingga mendapat pengaruh yang baik juga.

Faktor-faktor pendukung penerapan nilai-nilai budaya di Madrasah Muhammad Basiuni Imran adalah :

1. Tenaga pengasuh dan pengajar yang memadai

2. Santri/siswa sebagian besar berada dalam lingkungan pondok/ asrama, sehingga mudah untuk memonitor dan menggerakkan mereka

3. Kerjasama dan dukungan yang kuat dari siswa/santri dan orangtua

4. Lingkungan pondok/madrasah yang luas, nyaman dan kondusif

5. Rasa kekeluargaan yang kental antara siswa/santri, guru/pengasuh maupun pengurus pondok

Faktor-faktor penghambat penerapan nilai-nilai Budaya di Madrasah Muhammad Basiuni Imran adalah :

1. Kesiapan para siswa/santri terutama untuk menyesuaikan diri dengan suasana madrasah/pondok.

2. Kesulitan untuk memonitor para siswa/santri yang berada di luar lingkungan pondok, sehingga faktor lingkungan sosial dari luar juga perpengaruh terhadap penerapan nilai-nilai budaya di Madrasah 
3. Ada keluhan orangtua tentang jadwal kegiatan di Madrasah yang terlalu padat .

4. Masih ada guru yang datang terlambat.

5. Fasilitas dan prasarana yang belum memadai.

\section{Saran}

Dari hasil penelitian ini disarankan kepada kepala sekolah hendaknya kebiasaan warga sekolah yang selama ini telah berlangsung sudah menjadi karakter dan kekuatan sekolah sebaiknya dipertahankan dan ditingkatkan.

Kepada para pendidik yang setiap hari berhadapan dengan peserta didik dengan segala problematikanya, dapat memberikan kontribusi bagi pengembangan nilai-nilai kemanusiaan untuk bekal para anak didik agar memiliki karakter kuat untuk bisa menjadi manusia yang tidak hanya memiliki kecerdasan intelektual tapi juga akhlak serta memiliki kepekaan sosial.

Untuk sekolah dalam hal ini warga Madrasah Tsanawiyah Muhammad Basiuni Imran Sambas agar tetap berupaya untuk meningkatkan mutu dan prestasi akademik serta prestasi non akademik. Selain itu hubungan kerjasama dengan orang tua murid dan masyarakat yang selama ini telah terjalin hendaknya terus ditingkatkan.

\section{Daftar Pustaka}

Karmidah. 2007. Budaya Sekolah Pada SMP Berprestasi (Studi Kasus: Pola Interaksi Pemangku Kepentingan dan Terbentuknya Budaya Sekolah pada Sekolah Menengah Pertama Negeri 1 Piyungan Kabupaten Bantul,Provinsi DIY.Universitas Indonesia

Miles dan Huberman. 1992. Analisis Data Kualitatif. Jakarta : Universitas Indonesia

Muhaimin, Suti'ah dan Sugeng Listyo Prabowo. 2010. Manajemen Pendidikan. Aplikasinya dalam Penyusunan Rencana Pengembangan Sekolah/Madrasah. Jakarta: Kencana

Ridwan. 2009. Metode dan Teknik Menyusun Proposal Penelitian. Bandung: Alfabeta

Schein, Edgar H. 2004. Organizational Culture and Leadership. Oxford Jossey Bass Publisher, San Francisco. 
Suharsaputra, Uhur. 2010. Administrasi Pendidikan. Bandung: PT. Refika Aditama

Suherman, Ade. 2011. Pengaruh Budaya Sekolah dan Motivasi Kerja Guru Terhadap Mutu Pendidikan (http://blogspot.com/2011/06)

Syafaruddin. 2010. Kepemimpinan Pendidikan. Jakarta: PT. Ciputat Press 